\begin{tabular}{|c|c|c|}
\hline$A$ & $\begin{array}{c}\text { International Journal of Current Research } \\
\text { and Academic Review }\end{array}$ & \\
\hline $\begin{array}{l}\text { EXCELLENT } \\
\text { PUBLISHERS }\end{array}$ & $\begin{array}{c}\text { ISSN: 2347-3215 (Online) } \\
\text { Journal homepage: http://, Www.ijcrar.com } 11 \text { (November-2017) } \\
\end{array}$ & \\
\hline
\end{tabular}

doi: https://doi.org/10.20546/ijcrar.2017.511.005

\title{
Rendemen Analysis and Phytochemical Screening of Perinereis aibuhitensis Extracts
}

\author{
Andi Evi Erviani ${ }^{{ }^{*}}$ and Abdur Rahman Arif ${ }^{2}$
}

\author{
${ }^{I}$ Department of Biology, Faculty of Mathematics and Natural Sciences, University of Hasanuddin, Tamalanrea \\ 90245, Makassar, Indonesia \\ ${ }^{2}$ Department of Chemistry, Faculty of Mathematics and Natural Sciences, University of Hasanuddin, Tamalanrea \\ 90245, Makassar, Indonesia
}

*Corresponding author

\begin{abstract}
Polychaeta have enormous potential to be utilized as food, a rich protein alternative because it contains high protein and phytochemical compounds. Research on the phytochemical compound of Perinereis aibuhitensis has never been done, then in an effort to develop alternative food based on marine worm is very important to be done to identify phytochemical compounds contained in the Perinereis aibuhitensis and know the benefits for health. This research was analyzed descriptively. The results showed that the extract yield of $23.52 \%$ and Perinereis aibuhitensis extract contain compound phytochemical class of Alkalaoid, Flavonoid, Saponin, Triterpenoid / Steroid, and Tanin.
\end{abstract}

\section{Article Info}

Accepted: 28 October 2017

Available Online: 20 November 2017

\section{Keywords}

Perinereis aibuhitensis, Phytochemical screening, Alternative food

\section{Introduction}

Perinereis aibuhitensis is a one species of Polychaeta that we can find in the coastal area of Losari, Makassar, South Sulawesi. All this time, Polychaeta are only used as bait for fishing. Makassar people are largely unfamiliar with these marine worms and their potentials. This is due to a lack of information about these marine worms and their utilization. Sea worms have a high protein content but not yet optimally utilized in Indonesia.

Polychaeta have a fairly complete nutritional content that can be used as alternative food. The nutrients found in marine worms are proteins, fats, carbohydrates, ashes, fatty acids and amino acids, vitamins A, B1, B6, B12, E, and minerals $\mathrm{P}, \mathrm{I} 2, \mathrm{Ca}, \mathrm{Mg}, \mathrm{C}$ are almost equivalent to nutrient content on fish (Silaban, 2012). The extract of
Siphonosoma australe species proved to contain protein of $56.35 \%$, ash content $15.08 \%$, fat content $9.82 \%$ and carbohydrate levels of $5.06 \%$ (Nurhikma et al., 2017). There is also a wide variety of amino acids in Polychaeta, in which amino acids are very important to support of various physiological activities of the body. One of the amino acids found in Polychaeta is glutamic acid that has an important role in the metabolism of sugars and fats. In addition, glutamic acid in animals or plants can be used as an ingredient in the treatment of epilepsy, mental retardation, muscular dystrophy, ulcers, hypoglycemic coma, and side effects of insulin drugs for diabetes.

Phytochemical screening is a qualitative test of chemical compounds in plant parts, especially secondary metabolites which include flavonoids, alkaloids, saponins, tannins, and terpenoids. Phytochemical 
screening must meet several requirements among others simple, fast, can be done with minimal equipment (Nirwana et al., 2015; Nafisah et al., 2014).

One of the Polychaeta that have the potential to be cultivated in Makassar city is Perinereis aibuhitensis, which is widely found in the reclamation area of Losari Beach, Makassar City.

This Polychaeta is only used as a bait when fishing. The potential of this Polychaeta has not been utilized properly, due to lack of scientific information about the content of phytochemical compounds found in this Polychaeta.

Based on the above information and the limited information about the phytochemical compound of Perinereis aibuhitensis, so that in this research have been conducted phytochemical screening of Perinereis aibuhitensis extract as an effort to develop alternative food based on Polychaeta. Phytochemical screening was performed on Perinereis aibuhitensis extract to determine the content of bioactive compounds in Perinereis aibuhitensis which is beneficial for health.

\section{Materials and Methods}

\section{Study animals}

Materials used are $P$. Aibuhitensis obtained from Losari Beach reclamation area. The material used in the extraction is absolute ethanol, while the materials used in phytochemical screening are phytochemical screening reagents obtained from the Phytochemical Laboratory, Faculty of Pharmacy, Hasanuddin University.

\section{Extraction of Perinereis aibuhitensis}

P. aibuhitensis were taken as many as 1000 grams (Takahashi et al., 1995). The sample was washed with running water. The clean worm sample is then dried and smoothed using a blander. The refined $P$. aibuhitensis is used for the extraction process according to Purwaningsih et al., (2008). The extraction process is done by a 24 hour maceration method. The crushed from marine worms soaked using ethanol solvent in a ratio of 1:4 (w:v), macerated for 24 hours using a 24 hour-orbital shaker at room temperature then filtered using Whatman filter paper. Maseration is done as much as 3 x 24 hours. The resulting filtrate was separated solvent using a rotary vacuum evaporator at $40{ }^{\circ} \mathrm{C}$ for 6 hours. The resulting extract is then weighed.

\section{Analysis of Rendement and Phytochemical Screening}

The percentage of rendement of $P$. aibuhitensis extract can be calculated by formula: Rendement $(\%)=$ Weight of extract (g)/ Weight sample (g) x 100\%. Phytochemical screening is performed to determine the active component of a material. The analysis of ethanol extract includes examination of alkaloids, flavonoids, saponins, tannins, steroids and triterpenoids.

\section{Alkaloids}

A sample of $0.05 \mathrm{~g}$ was inserted into the test tube and then the addition of $\mathrm{H}_{2} \mathrm{SO}_{4} 2 \mathrm{~N}$ as much as two drops and shaken until completely mixed. Then poured into a drop plate and dropped Meyer's reagent by looking at the white precipitate. Wagner reagent by looking at brown precipitate and reagent 8 Dragendorff with orange precipitate, if there is a precipitate then the sample is said to be positive.

\section{Flavonoids}

Samples of $0.05 \mathrm{~g}$ were added $\mathrm{Mg}$ powder of $0.05 \mathrm{mg}$, then added $0.2 \mathrm{~mL}$ of amyl alcohol and $4 \mathrm{~mL}$ of $70 \%$ alcohol. The test results are positive when the solution is red, yellow or orange on the amyl alcohol layer.

\section{Saponin}

Saponin test can be detected by foam test in hot water. Samples of $0.05 \mathrm{~g}$ were placed in the test tube. Added hot water then the tubes shake. After the tube is shaken, it is left for 30 minutes and $\mathrm{HCl} 2 \mathrm{~N}$ added 1 drop. Saponin positive test results are shown in the presence of a stable foam.

\section{Tanin}

As much as $0.05 \mathrm{~g}$ sample added hot water, then the samples were dropped with $1 \% \mathrm{FeCl}_{3}$ as much as 2 drops. The test results are positive if the solution is dark blue or dark green.

\section{Steroid/Triterpenoid}

Samples of $0.05 \mathrm{~g}$ plus $2 \mathrm{ml}$ of chloroform were then dropped with acetic acid anhydride by 5 drops. After that drops with $\mathrm{H}_{2} \mathrm{SO}_{4} 2 \mathrm{~N}$ of 3 drops. The positive steroid test results when the color of the solution turns to blue, while the positive triterpenoid test results when a brownish red color on the surface layer of the sample. 


\section{Analisis Data}

The analysis was done that is the analysis of the extract rendement and the phytochemical screening analysis. The result of the observation was done descriptively.

\section{Results and Discussion}

\section{Rendemen Analysis}

Rendemen of the extract was calculated based on the ratio of the final weight (weight of extract produced after evaporation) with the initial weight (weight of biomass used) multiplied $100 \%$. Preparation of marine worm extract (Perinereis aibuhitensis), begins with weighing the simplicia Polychaeta that has been shaped powder, as much as 36.9 grams, then macerated by using ethanol absolute as much as $200 \mathrm{ml}$ for $1 \times 24$ hours. The extract was then filtered using a filter paper (filtrate 1), and the residue was extracted with $200 \mathrm{ml}$ of absolute ethanol for $1 \times 24$ hours. The extract was then filtered using a filter paper (filtrate 2), and the residue was extracted again using $200 \mathrm{ml}$ of ethanol absolute for $1 \mathrm{x} 24$ hours, then the extract was re-filtered using a filter paper (filtrate 3 ). Furthermore filtrate 1 , filtrate 2 , and filtrate 3 are collected in one container. The filtrate is further evaporated using a vacuum evaporator until the volume is reduced and produces marine worm extract of 8.68 grams. The rendemen of extract using ethanol solvent was $23,52 \%$ with time of extraction for 55 minutes. This relatively high rendemen can be affected by the solvent used, the ethanol solvent used has the same polarity properties as most of the components contained in cellular biomass Perinereis aibuhitensis. Several phytochemical compounds dissolved in a polar solvent so that the compound extracted with the ethanol solvent is considerable and and produce a high rendemen. It is supported by extracts that are dark brown.

\section{Phytochemical Screening}

Phytochemical compounds are secondary metabolite group compounds in living organisms that have certain functions for humans. Phytochemical compounds are secondary metabolite compounds in plants and animals that have certain functions for humans. To know the phytochemical compound, in this research has been done to identify five types of phytochemical compounds that are estimated to be found in marine worm extract Perinereis aibuhitensis. These phytochemical compounds are alkaloid group compounds, flavonoids, anthraquinones, steroid glycosides, flavonoid glycosides, and saponins. The identification results of phytochemical compounds on marine worm extract Perinereis aibuhitensis as presented in Table 1 .

The results of phytochemical screening showed that marine worm extract Perinereis aibuhitensis contains alkaloids, flavonoids, saponins, triterpenoids/ steroids and tannins. Alkaloids can be detected by precipitation using Mayer, Wagner, and Dragendorff reagents (Harborne, 1987). Alkaloid group compounds are often used for treatments such as antimalarials, antioxidants, asthma medications and have an antihyperglycemic effect (Tiong et al., 2013). According to Firdaus et al., (2004), alkaloids that have antihyperglycemic properties such as leurosine, leurosine sulphate, vindoline, and vindolinine.

Table.1 Phytochemical Screening Results of Perinereis aibuhitensis extract

\begin{tabular}{|l|l|c|}
\hline Phytochemical Test & Positive Results According to the Reference & Result \\
\hline Alkaloids & $\begin{array}{l}\text { Formed orange precipitate (Reagent } \\
\text { Dragendorff) }\end{array}$ & + \\
\hline Flavonoids & Color change occurs from the control tube & + \\
\hline Saponin & $\begin{array}{l}\text { There is a foam that survives in } 10 \text { minutes as } \\
\text { high as } 10 \mathrm{~cm}\end{array}$ & + \\
\hline Triterpenoid/Steroid & Ring is brown or violet & + \\
\hline Tanin & Formed in dark blue or blackish green & + \\
\hline
\end{tabular}

Description: + contained compounds

Other bioactive compounds are flavonoids which are polar compounds having hydroxyl or sugar groups, which can be soluble in polar solvents such as ethanol, methanol, butanol, acetone, dimethylsulfoxide, and water
(Harborne, 1987). According to Dheer and Bhatnagar (2010), flavonoids are substances that are able to regenerate pancreatic beta cells and help stimulate insulin secretion. This is in accordance with research 
conducted Brahmachari (2011) which states that flavonoids have hypoglycemic effects by reducing glucose absorption and regulate the activity of enzyme expression involved in carbohydrate metabolism.

The next bioactive compound is saponins. Firdous et al., (2009) states that saponin is an active compound that has a strong surface and can cause foam when shaken with water. The structure consists of aglycone (triterpene or steroid) and glucose group. Yoshikawa et al., (2005), states that saponins have many biological and pharmacological functions such as hemolysis, cardiotonic, hypoglycemic, hypocholesterolemic, immune modulator, hepatoprotection, antioxidant, and anticardiogenic. Saponins function as antihyperglycemic with mechanisms to prevent gastric emptying and prevent increased glucose uptake in intestinal brush border membranes.

Steroids are compounds that generally have cyclic structures and have hydroxyl groups (Harbone, 1987). The steroid fukosterol compounds isolated from marine biological resources are non-toxic and have the efficacy of lowering cholesterol in the blood and promoting antidiabetic activity. Mukhriani (2014) states that steroid compounds can be used as the basic ingredients for the manufacture of drugs. Nurulita et al., (2008) mentions steroid compounds are active components that have been used for the treatment of diabetes, menstrual disorders, as antibacterial and antiviral.

Differences in results obtained according to Iswantini et al., (2011) allegedly due to differences in environmental conditions. Different environmental conditions can cause different types and amounts of secondary metabolites contained in a material.

Widarta et al., (2013) mention the difference of type and level of solvency polarity can produce different rendemen of extract and bioactive component. Sompong et al., (2010) suggests that species and plant different species produce different bioactive components.

In this research, the extraction result using ethanol absolute solvent was obtained rendemen extract of $23,52 \%$. The result of phytochemical screening by Thin Layer Chromatography method showed that marine worm extract by using absolute ethanol solvent contains phytochemical compound of alkaloid, flavonoid, saponin, triterpenoid/ steroid, and tannin as indicated by the appearance of specific color stain on silica gel of Thin Layer Chromatography.

\section{References}

Al-Hakim, II. 1991. Paraprionospio pinnata (Ehlers, 1901) (Polychaeta: Spionidae), Possible Utilization as Animal Bioindicator. Oseana, 16(2): 21-34.

Al-Hakim, II., \& Puji SW. 2009. Population of Syllidae familia (Polychaeta) at Seagrass Waters of Gilimanuk Bay. Oceanologi dan Limnologi di Indonesia, 35(1): 29-45.

Brahmachari G. 2011. Bio-flavonoids with Promising Antidiabetic Potentials: Acritical Survey. Research Signpost. 661(2): 187-212.

Dheer R, Bhatnagar P. 2010. A study of the antidiabetic activity of Barleriaprionitis Linn. Indian Journal of Pharmacology. 42(2): 1-5.

Erviani, Trijoko, dan Hadisusanto S. 2015. Character Morphology and Substrate Polychaeta In Losari Beach, Makassar City, South Sulawesi. Jurnal Alam dan Lingkungan, Vol.6 (12):29-35.

Firdaus RT, Suhartono E, Qamariah N. 2004. Modeling of glycosylation reactions and the role of tapak dara infusions (Catharantus roseus [L] G. Don) sebagai penghambat kerusakan protein. Berkala Ilmu Kedokteran. 36(1): 1-6.

Firdous M, Koneri R, Sarvaraidu CH, Shubhapriya KH. 2009. NIDDM antidiabetic activity of saponins of Momordica cymbalaria in streptozotocinnicotinamide NIDDM mice. Journal of Clinical and Diagnosis Research. 3: 1460-1465.

Harborne JB. 1987. Metode Fitokimia. Edisi ke-2. Padmawinata K, Soediro I, Penerjemah. Bandung (ID): Institut Teknologi Bandung. Terjemahan dari: Phytochemical methods. [IFCC] International Federation of Clinical Chemistry. 2002. Commitee on reference system for enzymes, Chemical Clinic Laboratorium Medic. 40(7): 725-733.

Iswantini D, Silitonga RF, Martatilofa E, Darusman LK. 2011. Zingiber cassumunar, Guazuma ulmifolia, and Murray paniculata extracts as antiobesity: in vitro inhibitory effect on pancreatic lipase activity. Hayati Journal of Bioscience. 18 (1): 6-10.

Mukhriani, 2014. Extraction, separation of compounds, and identification of active compounds. Jurnal Kesehatan. 7(2): 361-367.

Nafisah M, Tukiran, Suyatno, Hidayati N. 2014. Phytochemical Screening Test on Hexane Extracts, Chloroform and Methanol from Euphorbiae hirtae. Proceedings of the National Seminar on Chemistry. ISBN: 978-602-0951-00-3.

Nurhikma, Nurhayati T, Purwaningsih S. 2017. Amino Acid Content, Fatty Acid, and Mineral Marine Worm from Southeast Sulawesi. JPHPI, 20(1). 
Nurulita Y, Haryanto D, Andreanus AS. 2008. Screening of activities and antidiabetic compounds of Clinacanthus nutans leaf water extract. Jurnal Natur Indonesia. 10(2): 98-103.

Sani RN, Nisa FC, Andriani RD, Maligan JM. 2014. Analysis of Rendement and Screening of Microalgae Phytochemical Extract. Jurnal Pangan dan Industri, 2(2): 121-126.
Sompong R, Siebenhandl ES, Linsberger MG, Berghofer E. 2011. Physicochemical and antioxidative properties of red and black rice varieties from Thailand, China and Sri Lanka. Journal of Food Chemistry. 124: 132-140.

Wills ED. 1987. Biochemical Toxicology, a Practical Approach. Oxford (UK): IRL Press Limited.

Yusron E. 1985. Some Notes Regarding Marine Worms (Polychaeta). Oseana, Volume 9(4): 122-127.

\section{How to cite this article:}

Andi Evi Erviani and Abdur Rahman Arif. 2017. Rendemen Analysis and Phytochemical Screening of Perinereis aibuhitensis Extracts. Int.J.Curr.Res.Aca.Rev. 5(11), 25-29. doi: https://doi.org/10.20546/ijcrar.2017.511.005 